\title{
Up-regulation of endothelin type B receptors in the human internal mammary artery in culture is dependent on protein kinase $C$ and mitogen-activated kinase signaling pathways David Nilsson1, Lotta Gustafsson ${ }^{1}$, Angelica Wackenfors1, Bodil Gesslein 1,2, Lars Edvinsson ${ }^{1}$, Per Paulsson ${ }^{3}$, Richard Ingemansson ${ }^{3}$ and Malin Malmsjö*1,2
}

Address: ${ }^{1}$ Department of Medicine, Lund University Hospital, Sweden, ${ }^{2}$ Department of Ophthalmology, Lund University Hospital, Sweden and ${ }^{3}$ Department of Cardiothoracic Surgery, Lund University Hospital, Sweden

Email: David Nilsson - david.nilsson@med.lu.se; Lotta Gustafsson - lotta.gustafsson@med.lu.se;

Angelica Wackenfors - angelica.wackenfors@med.lu.se; Bodil Gesslein - bodil.gesslein@med.lu.se; Lars Edvinsson - lars.edvinsson@med.lu.se; Per Paulsson - per.paulsson@skane.se; Richard Ingemansson - richard.ingemansson@skane.se; Malin Malmsjö* - malin.malmsjo@med.lu.se

* Corresponding author

Published: 8 September 2008

BMC Cardiovascular Disorders 2008, 8:21 doi:10.1|86/|47|-226I-8-21

This article is available from: http://www.biomedcentral.com/|47|-226I/8/2I

(C) 2008 Nilsson et al; licensee BioMed Central Ltd.

This is an Open Access article distributed under the terms of the Creative Commons Attribution License (http://creativecommons.org/licenses/by/2.0), which permits unrestricted use, distribution, and reproduction in any medium, provided the original work is properly cited.
Received: 19 March 2008

Accepted: 8 September 2008

\begin{abstract}
Background: Up-regulation of vascular endothelin type $B\left(E T_{B}\right)$ receptors is implicated in the pathogenesis of cardiovascular disease. Culture of intact arteries has been shown to induce similar receptor alterations and has therefore been suggested as a suitable method for, ex vivo, in detail delineation of the regulation of endothelin receptors. We hypothesize that mitogen-activated kinases (MAPK) and protein kinase $C$ (PKC) are involved in the regulation of endothelin $E T_{B}$ receptors in human internal mammary arteries.

Methods: Human internal mammary arteries were obtained during coronary artery bypass graft surgery and were studied before and after 24 hours of organ culture, using in vitro pharmacology, real time PCR and Western blot techniques. Sarafotoxin $6 \mathrm{c}$ and endothelin-I were used to examine the endothelin $\mathrm{ET}_{\mathrm{A}}$ and $\mathrm{ET}_{\mathrm{B}}$ receptor effects, respectively. The involvement of $\mathrm{PKC}$ and MAPK in the endothelin receptor regulation was examined by culture in the presence of antagonists.
\end{abstract}

Results: The endohtelin-I-induced contraction (after endothelin $\mathrm{ET}_{\mathrm{B}}$ receptor desensitization) and the endothelin $\mathrm{ET}_{\mathrm{A}}$ receptor $\mathrm{mRNA}$ expression levels were not altered by culture. The sarafotoxin $6 c$ contraction, endothelin $\mathrm{ET}_{\mathrm{B}}$ receptor protein and mRNA expression levels were increased after organ culture. This increase was antagonized by; (I) PKC inhibitors ( $10 \mu \mathrm{M}$ bisindolylmaleimide I and $10 \mu \mathrm{M}$ Ro-32-0432), and (2) inhibitors of the p38, extracellular signal related kinases I and 2 (ERKI/2) and C-jun terminal kinase (JNK) MAPK pathways (I $0 \mu$ M SB203580, $10 \mu$ M PD 98059 and $10 \mu \mathrm{M}$ SP600 I25, respectively).

Conclusion: In conclusion, PKC and MAPK seem to be involved in the up-regulation of endothelin $\mathrm{ET}_{\mathrm{B}}$ receptor expression in human internal mammary arteries. Inhibiting these intracellular signal transduction pathways may provide a future therapeutic target for hindering the development of vascular endothelin $\mathrm{ET}_{\mathrm{B}}$ receptor changes in cardiovascular disease. 


\section{Background}

Endothelin-1 is a potent vasoconstrictor produced by endothelial cells. It is a vasoactive agent that mediates multiple vascular actions and plays an important role in hypertension and cardiovascular diseases by promoting changes in vascular reactivity and endothelial function, cardiovascular fibrosis, tissue remodeling, inflammation, and oxidative stress. Endothelin exerts its effect through two different $G$ protein coupled receptors, the endothelin type $A\left(\mathrm{ET}_{\mathrm{A}}\right)$ receptor and the endothelin type $\mathrm{B}\left(\mathrm{ET}_{\mathrm{B}}\right)$ receptor [1-3]. The endothelin $\mathrm{ET}_{\mathrm{A}}$ receptors are expressed in vascular smooth muscle cells and mediate vasoconstriction. In healthy conditions, endothelin $\mathrm{ET}_{\mathrm{B}}$ receptors are mainly located on endothelial cells and mediate vasodilatation via the release of nitric oxide, prostaglandins and endothelium-derived hyperpolarizing factor [4-6]. However, endothelin $\mathrm{ET}_{\mathrm{B}}$ receptors on vascular smooth muscle cells have been observed to be upregulated during pathological conditions such as atherosclerosis [7], congestive heart failure [8], ischemic heart disease [9] and hypertension [10]. Endothelin receptors on vascular smooth muscle cells are both mitogenic, leading to atherosclerosis, and mediate strong vasoconstriction which may lead to elevated vascular tone frequently observed in cardiovascular disease.

Endothelin receptor regulation can be studied in detail, ex vivo, using organ culture of intact arteries. Endothelin $\mathrm{ET}_{\mathrm{B}}$ receptors on smooth muscle cells are up-regulated when whole blood vessels are incubated for 12 to 48 hours [11]. Furthermore, endothelin $\mathrm{ET}_{\mathrm{B}}$ receptors are up-regulated in human coronary arteries after organ culture, in a similar way as in ischemic heart disease in man [12]. Endothelin receptor-changes also occur during organ culture in rat cerebral and peripheral arteries, mimicking that observed in peripheral artery disease, stroke and subarachnoidal haemorrhage [13-15]. Detailed delineation of the regulation of vascular endothelin receptors can be performed by culture in the presence of different humoral factors or intracellular signal transduction pathway inhibitors.

We aim to identify the intracellular signal transduction pathways that regulate the expression of endothelin receptors in the vasculature. These may provide future therapeutic targets for hindering the development of vascular endothelin receptor changes in cardiovascular disease. In a previous study, culture of porcine coronary arteries shows that protein kinase $\mathrm{C}$ (PKC) and mitogen activated protein kinases (MAPKs) are signaling pathways that regulate endothelin receptor expression [16]. Other studies, using rat cerebral arteries, show similar results $[17,18]$. Hitherto, the regulation of endothelin receptors have mainly been studied in animals and data from humans barely exists. When identifying new targets for pharmaceutical intervention, it is of importance that the research is performed not only in animals, but also in patients. In the present study, internal mammary arteries from patients undergoing coronary artery bypass graft surgery were studied to examine the role of PKC and MAPK in the endothelin $\mathrm{ET}_{\mathrm{A}}$ and $\mathrm{ET}_{\mathrm{B}}$ receptor regulation in humans.

PKC is a family of serine/threonine kinases participating in signal transduction events in response to specific hormonal, neuronal and growth factor stimuli. MAPKs represent another group of serine/threonine kinases that are thought to act downstream from PKC in the smooth muscle cell regulatory cascade [19]. There are three major groups of distinctly regulated MAPKs leading to altered gene expression in humans. The extracellular signal related kinases 1 and 2 (ERK1/2), the C-jun terminal kinase (JNK) and the p38 MAPK are known to play important roles in the intracellular signalling in response to extracellular stimuli [20]. Upon activation, MAPKs cause phosphorylation and activation of transcription factors present in the cytoplasm or nucleus, thereby leading to expression of target genes resulting in biological responses [21].

In the present study, we use the organ culture model to examine the involvement of PKC and MAPK pathways in the regulation of endothelin receptors in the human internal mammary artery. Arterial segments are cultured for 24 hours in the absence or presence of PKC inhibitors (Ro32-0432 and bisindolylmaleimide I) and inhibitors of the three major MAPK pathways in mammals (p38 MAPK, ERK1/2 and JNK). The contractile effects and the levels of endothelin $\mathrm{ET}_{\mathrm{A}}$ and $\mathrm{ET}_{\mathrm{B}}$ receptor protein and mRNA expression are evaluated using in vitro pharmacology, real time PCR and Western blot techniques.

\section{Methods \\ Tissue collection}

During coronary artery bypass graft surgery, one end of the left mammary artery is harvested and sutured to the coronary artery, distal to the stenosis. A segment of the artery is sometimes removed when the artery is adjusted to an appropriate length for the grafting procedure. The artery segment that is removed can be used for research without affecting the patient. For the present study, the left internal mammary artery, from 27 patients undergoing coronary artery bypass graft surgery, was used for experimental analysis. The patients' median age was 70 years and ranged from 43 to 85 years. Twenty-one men and 6 women were included in the study. After dissection during surgery, the vessels were immediately immersed into cold sterile Dulbeccos' modified Eagles' medium (DMEM), transported to the laboratory on dry ice and used for the experiments. In the laboratory, the arteries were dissected free from adhering tissue, and then cut into cylindrical segments (3-4 mm long). 


\section{Ethics}

The study was approved by the Ethics Committee of Lund University in Sweden and is in accordance with the Declaration of Helsinki.

\section{Organ culture procedure}

The artery segments were divided into two groups; one that was not cultured (control) and one that was cultured for 24 hours. The artery segments for culture were placed in a 48 well plate, one segment in each well, containing 1 $\mathrm{ml}$ DMEM and incubated for 24 hours at $37^{\circ} \mathrm{C}$ in humidified 5\% $\mathrm{CO}_{2}$ in air. DMEM (Gibco BRL, Praisley, UK) was serum free and contained D-glucose $(1 \mathrm{~g} / \mathrm{l})$, sodium pyruvate $(100 \mathrm{mg} / \mathrm{l})$ and was supplemented with penicillin (100 U/ml), streptomycin $(100 \mu \mathrm{g} / \mathrm{ml})$ and amphotericin B $(0.25 \mu \mathrm{g} / \mathrm{ml})$. The method of blood vessel culture has been described previously [11]. The segments were cultured in the absence or presence of:

\section{(I) PKC inhibitors}

- Ro-32-0432 (10 $\mu \mathrm{M})$, 2-8-[(Dimethylamino)methyl]6,7,8,9-tetrahydropyrido [1,2-a]indol-3-yl \}-3-(1-methyl1H-indol-3-yl)maleimide.

- Bisindolylamaleimide I (10 $\mu \mathrm{M}), 2$-[1-(3-Dimethylaminopropyl)-1H-indol-3-yl]-3-(1H-indol-3-yl)-maleimide.

\section{(2) MAPK inhibitors}

- The p38 MAPK inhibitor, SB 203580 (10 $\mu \mathrm{M})$, 4-(4Fluorophenyl)-2-(4-methylsulfinylphenyl)-5-(4-pyridyl)1H-imidazole.

- The ERK1/2 inhibitor, PD $98059(10 \mu \mathrm{M}), 2$-(2-Amino3-methoxyphenyl)-4H-1-benzopyran-4-one.

- The JNK inhibitor, SP600125 (10 $\mu \mathrm{M})$, 1,9-Pyrazoloanthrone Anthrapyrazolone.

\section{In vitro pharmacology}

For the in vitro pharmacology experiments, the arterial segments were mounted on two L-shaped metal prongs, one of which was connected to a force displacement transducer for continuous recording of the isometric tension [22]. The mounted segments were immersed in temperature controlled $\left(37^{\circ} \mathrm{C}\right)$ tissue baths containing a bicarbonate based buffer solution of the following composition; $\mathrm{NaCl}(119 \mathrm{mM}), \mathrm{NaHCO}_{3}(15 \mathrm{mM}), \mathrm{KCl}(4.6 \mathrm{mM}), \mathrm{MgCl}$ $(1.2 \mathrm{mM}), \mathrm{NaH}_{2} \mathrm{PO}_{4}(1.2 \mathrm{mM}), \mathrm{CaCl}_{2},(1.5 \mathrm{mM})$ and glucose $(5.5 \mathrm{mM})$, which was continuously gassed with $5 \%$ $\mathrm{CO}_{2}$ in $\mathrm{O}_{2}$ resulting in a $\mathrm{pH}$ of 7.4. Eight to sixteen segments were studied at the same time in separate tissue baths. The segments stabilized at a resting tension of 4 $\mathrm{mN}$ for one hour before the experiments were started. Previous results show that a resting tension of 3 to $5 \mathrm{mN}$ provides optimal conditions for studying vascular contraction in the human left internal mammary artery [23]. The contractile capacity of each arterial vessel segment was examined by exposure to a potassium rich (63.5 $\mathrm{mM}$ ) buffer solution.

The endothelin $\mathrm{ET}_{\mathrm{B}}$ receptor agonist, sarafotoxin $6 \mathrm{c}$, was first added at increasing concentrations $\left(10^{-11}-10^{-6} \mathrm{mM}\right)$. The arteries were washed and endothelin-1 was therafter added at increasing concentrations $\left(10^{-11}-10^{-6} \mathrm{mM}\right)$. At this stage the endothelin $\mathrm{ET}_{\mathrm{B}}$ receptors were desensitized [24], allowing endothelin-1 to act selectively on endothelin $\mathrm{ET}_{\mathrm{A}}$ receptors.

The sarafotoxin $6 c$ experiments were run in the absence (control) and presence of the selective endothelin $\mathrm{ET}_{\mathrm{B}}$ receptor antagonist BQ788 ((N-cis-2,6-dimethyl-piperidinocarbonyl-L- $\gamma$-methylleucyl-D-1-methoxycarbonyltryptophanyl-D-norleucine, $0.1 \mu \mathrm{M}$ ), added $15 \mathrm{~min}$ prior to sarafotoxin $6 \mathrm{c}$.

Previous results from human internal mammary arteries show a variation in the expression of the vasoconstricting endothelin $\mathrm{ET}_{\mathrm{B}}$ receptors and only $58 \%$ of the patients that undergo coronary artery bypass graft surgery have graft vessels that express these receptors [23]. Other studies have shown similar irregularity in the endothelin response [25]. In the present study, $44 \%$ of the examined arteries (patients) responded to sarafotoxin 6c. For the in vitro pharmacology experiments, using BQ788, only the arteries that responded to sarafotoxin $6 \mathrm{c}$ was used. For the other experiments, both the arteries that responded and the arteries that did not respond to sarafotoxin $6 \mathrm{c}$ were used for the experiments, calculations and results.

All drugs for the in vitro pharmacological experiments were purchased from Sigma Chemical Co (St. Louis, MO). Endothelin-1 and sarafotoxin 6c were dissolved in $0.9 \%$ $\mathrm{NaCl}$ with $10 \%$ albumin and BQ788 were dissolved in $0.9 \%$ saline. The PKC and MAPK inhibitors were dissolved in dimethylsulphoxide (0.01 M DMSO in $0.9 \%$ saline, Calbiochem ${ }^{\circledR}$, Darmstadt, Germany).

\section{Real time PCR}

The arteries for real time PCR experiments were frozen in liquid nitrogen and stored at $-80^{\circ} \mathrm{C}$ until the experiments were performed. Endothelin $\mathrm{ET}_{\mathrm{A}}$ and $\mathrm{ET}_{\mathrm{B}}$ receptor mRNA expression levels were quantified by real time PCR. Total cellular RNA was extracted using TRIzol ${ }^{\circledR} \mathrm{LS}$ according to the supplier's instructions (Life Technologies, Paisley, $\mathrm{UK})$. Reverse transcription of total RNA to cDNA was carried out using the Gene Amp RNA PCR kit in a DNA Thermal cycler (Perkin-Elmer Applied Biosystems, Foster City, CA, USA). Real time PCR was performed with the GeneAmp SYBR Green PCR kit (PE Applied Biosystems) in a Perker-Elmer real time PCR machine 7300. 
The cDNA synthesized above served as template in a (25 $\mu \mathrm{l})$ reaction. A non-template control was included in all experiments. The GeneAmp 7300 sequence detection system monitored the binding of a fluorescent dye to doublestrand DNA by real time detection of the fluorescence during each cycle of PCR amplification. Specific primers were designed as follows:

$\mathrm{ET}_{\mathrm{A}}$ receptor GenBank: NM_001957 forward; 5'-ATTGCCCTCAGCGAACAC-3' reverse; 5'-CAACCAAGCAGAAAGACGGTC-3' ET $_{\mathrm{B}}$ receptor GenBank: NM 000115 forward; 5'-GATACGACAACTTCCGCTCCA-3' reverse; 5'GTCCACGATGAGGACAATGAG-3' $\beta$-actin GenBank: NM 001101 forward; 5'-AAGGCCAACCGCGAGAA-3' reverse; 5'-ACAGCC TGGATAGCAACGTACA-3' GAPDH GenBank: NM 002046 forward; 5'-CACCAGGGCTGCTTT TAACTCT-3' reverse; 5'-CTTGACGGTGCCATGGAATT-3'

The housekeeping genes, $\beta$-actin and glyceraldehyde 3 phosphate dehydrogenase (GAPDH) were used as references due to their continuous expression in cells. The real time PCR reaction was performed at a temperature of $50^{\circ} \mathrm{C}$ for $2 \mathrm{~min}, 95^{\circ} \mathrm{C}$ for $10 \mathrm{~min}$, and the following 40 PCR cycles with $95^{\circ} \mathrm{C}$ for $15 \mathrm{~s}$ and $60^{\circ}$ for $1 \mathrm{~min}$. Oligonucleotides and reagents for the PCR assay were purchased from Perkin-Elmer, Applied Biosystems Foster City, CA, USA.

\section{Western Blot}

Preparation of cell lysates

Whole cell extracts from the human internal mammary arteries were prepared by adding $300 \mu$ of RIPA buffert (50 mM Tris, $\mathrm{pH}$ 8.0, 1.0\% Igepal CA-630, 0.5\% sodium deoxycholate, $0.1 \%$ SDS, $150 \mathrm{mM} \mathrm{NaCl}$ ) supplemented with $0.37 \mathrm{~g} / \mathrm{ml}$ Complete protease inhibitor cocktail (Roche Diagnostics, Mannheim, Germany). By using a Tissue Lyser (Retsch GmbH, Haan, Germany) the samples were homogenized for 3 minutes at maximum frequency. Thereafter, the samples were incubated for 2 hours under gentle rocking at $4{ }^{\circ} \mathrm{C}$, where after the samples were centrifuged at $12000 \mathrm{~g}$ for $20 \mathrm{~min}$ and the supernatant was collected for protein concentration determination (Protein Assay Dye, Bio Rad, CA, USA).

\section{Experimental procedure}

Cell extracts were denatured in LDS sample buffer for 5 min in $95^{\circ} \mathrm{C}$, run on SDS-PAGE (NUPAGE, $4-12 \%$ BisTris, Invitrogen, Carlsbad, CA, USA) and blotted onto PVDF membrabes $(0.2 \mu \mathrm{m}$, Invitrogen $)$. Membranes were blocked with $2 \%$ non-fat dried milk for 1 hour and incubated with 1:100 goat polyclonal antibodies to human $\mathrm{ET}_{\mathrm{B}}$ receptor (C-20, sc-21196, Santa Cruz Biotechnology, Santa Cruz, Ca, USA) and 1:1000 HRP-coupled donkey anti-goat secondary antibody (DakoCytomation, Glos- trup, Denmark). The membrane was developed by using the ECL Plus Western Blotting Reagent (GE Healthcare, Little Chalfont, UK) and Fuji Film LAS-1000 equipment (Fuji Film, Tokyo, Japan). Parallel membranes were incubated with 1:5000 mouse monoclonal antibodies to betaactin (C4, sc-47778, Santa Cruz Biotechnology) and HRPcoupled rabbit anti-mouse secondary antibody (DakoCytomation). Primary and secondary antibody solutions were prepared in PBS solution containing 2\% bovine serum albumin $0.1 \%$ Tween-20. After incubation with antibodies, the membranes were washed 3 times and 5 min in PBS containing 0.1\% Tween-20.

\section{Calculations and statistics}

Calculations and statistics were performed using Graph Pad 4.0 software. Statistical analysis was performed using Student's t-test when comparing two groups and ANOVA with Dunnett's post-test for multiple comparisons when comparing three groups or more. $\mathrm{P}<0.05$ was considered significant. The results are expressed as mean \pm standard error of the mean (S.E.M.).

In vitro pharmacology

The maximum contraction $\left(\mathrm{E}_{\max }\right)$ was calculated as percentage of the contractile capacity of $63.5 \mathrm{mM}$ potassium. The negative logarithm of the concentration that elicited $50 \%$ contraction $\left(\mathrm{pEC}_{50}\right)$ was determined by linear regression analysis using the values immediately above and below half-maximum response.

Real time $P C R$

The amount of endothelin $\mathrm{ET}_{\mathrm{A}}$ and $\mathrm{ET}_{\mathrm{B}}$ receptor mRNA expression was calculated as relative to the amount GAPDH or $\beta$-actin in the same sample by the formula $\mathrm{X}_{0} /$ $\mathrm{R}_{0}=2$ CtR-CtX, where $\mathrm{X}_{0}=$ amount of endothelin $\mathrm{ET}_{\mathrm{B}}$ mRNA, $\mathrm{R}_{0}=$ original amount of GAPDH or $\beta$-actin mRNA, $\mathrm{CtR}=\mathrm{Ct}$ value for GAPDH or $\beta$-actin and $\mathrm{CtX}=\mathrm{Ct}$ value for the endothelin $\mathrm{ET}_{\mathrm{A}}$ and $\mathrm{ET}_{\mathrm{B}}$ receptor mRNA.

\section{Results \\ Effects of organ culture on endothelin $E T_{A}$ and $E T_{B}$ receptors}

The endothelin $\mathrm{ET}_{\mathrm{B}}$ receptor mediated contraction was studied using the selective agonist sarafotoxin $6 \mathrm{c}$. The endothelin-1-induced vasoconstriction was studied after desensitizing the endothelin $\mathrm{ET}_{\mathrm{B}}$ receptors with sarafotoxin $6 \mathrm{c}$ prior to adding endothelin-1, leaving only endothelin $\mathrm{ET}_{\mathrm{A}}$ receptors to respond.

Endothelin-1 induced potent contractions in the human internal mammary arteries studied (Fig. 1). In vitro pharmacology and real-time PCR experiments demonstrated similar endothelin-1 contractions and endothelin $\mathrm{ET}_{\mathrm{A}}$ receptor mRNA levels before and after organ culture $(\mathrm{P}=$ n.s., $\mathrm{n}=27$ and 8 respectively, Fig. 1 ). 

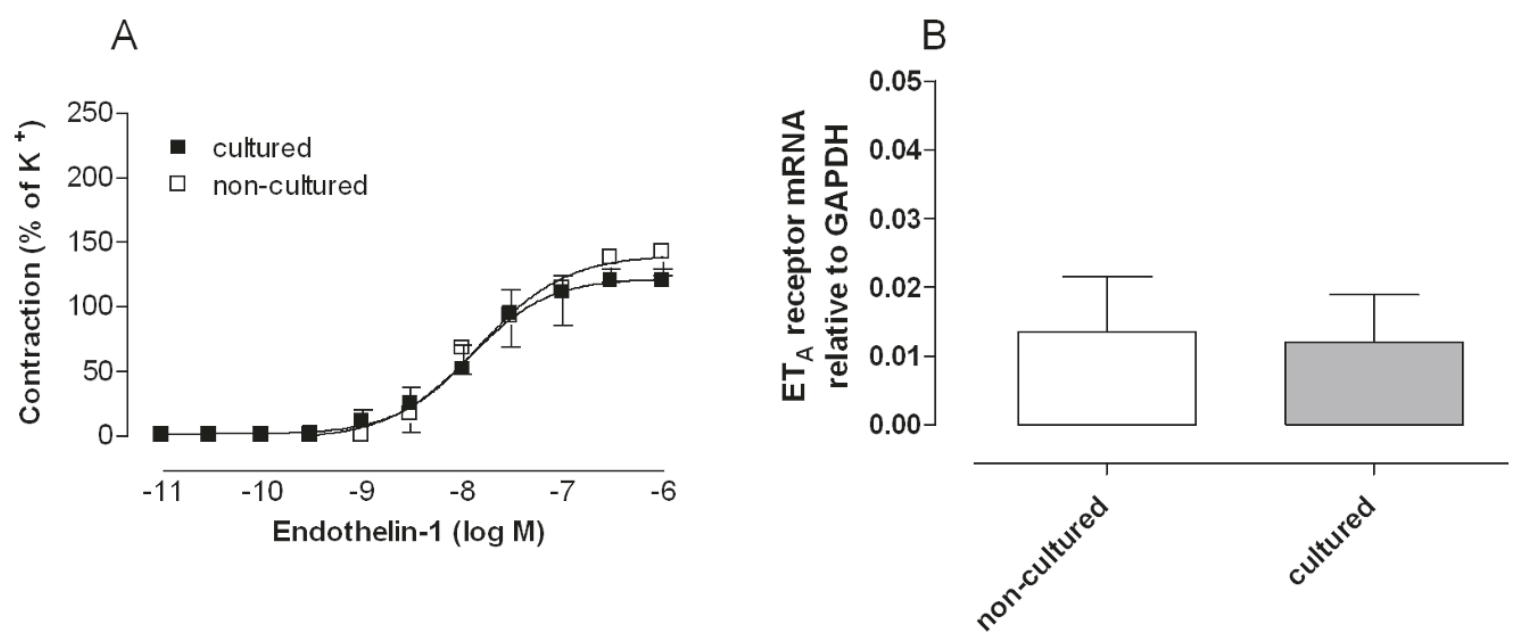

Figure I

(A) Endothelin- I contractions (after ET $_{B}$ receptor desensitisation) and (B) ET $_{A}$ receptor mRNA levels in cultured and non-cultured human internal mammary arteries, examined using in vitro pharmacology $(n=27)$ and real time PCR $(\mathbf{n}=\mathbf{8})$ experiments. The results are shown as mean values \pm S.E.M. Statistical analyses, comparing cultured with non-cultured, were performed using Student's t-test. There were no significant differences.

The endothelin $\mathrm{ET}_{\mathrm{B}}$ receptor agonist, sarafotoxin $6 \mathrm{c}$, induced contraction in $44 \%$ of the left internal mammary arteries (patients) studied $(\mathrm{n}=27)$. The sarafotoxin $6 \mathrm{c}$ contraction was inhibited by the selective endothelin $\mathrm{ET}_{\mathrm{B}}$ receptor antagonist, $\mathrm{BQ788}(\mathrm{P}<0.05, \mathrm{n}=6$, Fig. 2$)$. Both

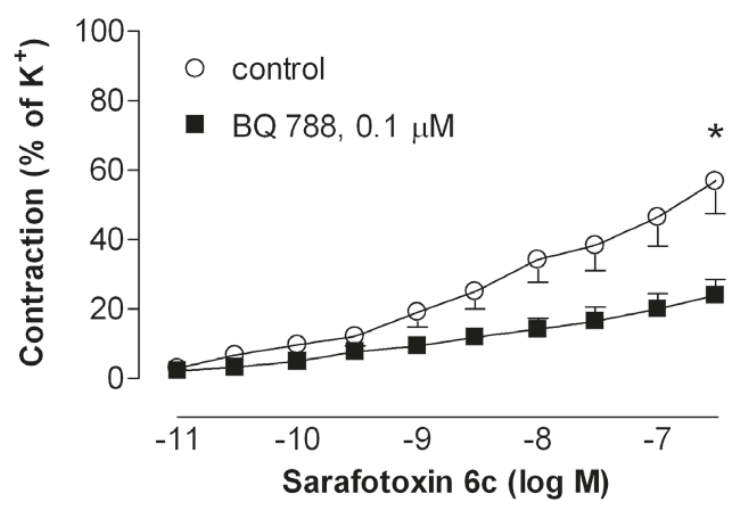

Figure 2

Contractile responses elicited by cumulative application of sarafotoxin $6 \mathrm{c}$ in non-cultured segments of human internal mammary arteries in the absence (control) and presence of $0.1 \mu \mathrm{mol} / \mathrm{I} \mathbf{B Q 7 8 8}$. The results are shown as mean values \pm S.E.M of six experiments. Statistical analyses of the maximum contraction, comparing control with BQ 788, was performed using Student's t-test, where $\mathrm{P}<0.05\left(^{*}\right)$ was considered significant. the arteries that responded and the arteries that did not respond to sarafotoxin $6 \mathrm{c}$ were used for further experiments, as described below.

The efficacy of the sarafotoxin 6c-contraction was significantly increased after culture $(\mathrm{p}<0.01, \mathrm{n}=27$, Fig. 3 ) suggesting up-regulated endothelin $\mathrm{ET}_{\mathrm{B}}$ receptors. Similarly, Western blot and real time PCR experiments demonstrated elevated levels of endothelin $\mathrm{ET}_{\mathrm{B}}$ receptor protein and mRNA expression, respectively, after culture $(\mathrm{P}<$ $0.05, \mathrm{n}=6$, Figure 4 ).

For the real time PCR experiments, similar patterns of endothelin $\mathrm{ET}_{\mathrm{A}}$ and $\mathrm{ET}_{\mathrm{B}}$ receptor mRNA expression could be shown when using $\beta$-actin as the reference gene as when using GAPDH (data not shown), indicating that these genes were trustworthy as references.

\section{Inhibition of PKC}

The increased sarafotoxin $6 c$ contraction and endothelin $\mathrm{ET}_{\mathrm{B}}$ receptor protein and mRNA expression levels during organ culture were inhibited when the arteries were cultured in the presence of the PKC inhibitors, Ro-32-0432 $(10 \mu \mathrm{M})$ and bisindolylmaleimide I $(10 \mu \mathrm{M})$. For results, numbers and statistics, see Fig. 3 and 4.

\section{Inhibition of MAPK}

The p38 MAPK pathway inhibitor, SB203580 (10 $\mu \mathrm{M})$, the ERK1/2 pathway inhibitor, PD98059 $(10 \mu \mathrm{M})$ and the JNK pathway inhibitor, SP600125 $(10 \mu \mathrm{M})$, inhibited the 

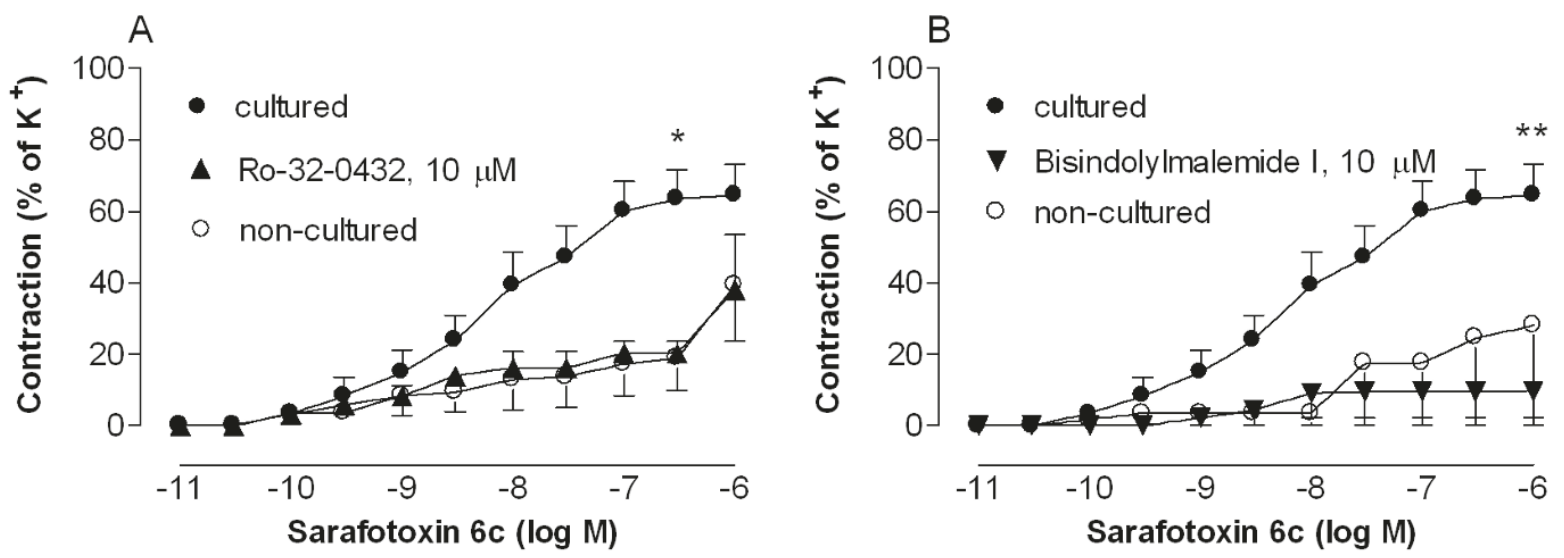

Figure 3

Contractile responses elicited by cumulative application of the endothelin $\mathrm{ET}_{\mathrm{B}}$ receptor agonist sarafotoxin $6 \mathrm{c}$ in segments of human internal mammary arteries. The arterial segments were either not cultured or cultured in the absence or presence of the protein kinase $C$ inhibitors (A) Ro-32-0432 or (B) bisindolylmaleimide I. The results are shown as mean values \pm S.E.M of six experiments. Statistical analysis was performed using ANOVA with Dunnett's post-test for multiple comparisons. $\mathrm{P}<0.05\left(^{*}\right)$ and $\mathrm{P}<0.0 \mathrm{I}\left({ }^{* *}\right)$ was considered significant. Comparisons were made between the results from arteries exposed to culture with and without Ro-32-0432 or bisindolylmaleimide I.

up-regulation of sarafotoxin $6 \mathrm{c}$ contraction, endothelin $\mathrm{ET}_{\mathrm{B}}$ receptor protein and mRNA expression. For results, numbers and statistics, see Fig. 5 and 6.

\section{Discussion \\ Main findings}

Up-regulation of vascular endothelin $\mathrm{ET}_{\mathrm{B}}$ receptors is implicated in the pathogenesis of cardiovascular disease. This study demonstrates that the PKC and MAPK intracellular signal transduction pathways may play a role in the regulation of endothelin $\mathrm{ET}_{\mathrm{B}}$ receptors in the human internal mammary artery.

\section{Organ culture and endothelin receptor regulation}

The organ culture method, used in the present study, stimulate up-regulation of endothelin $\mathrm{ET}_{\mathrm{B}}$ receptors in the human left internal mammary artery, as shown by in vitro pharmacology, Western blot and real time PCR experiments. This is in accordance with our previous findings that endothelin $\mathrm{ET}_{\mathrm{B}}$ receptors are up-regulated during organ culture in human coronary arteries [9]. This increase in $\mathrm{ET}_{\mathrm{B}}$ receptor density can be compared to that observed in arteries from patients with ischemic heart disease or hypertension $[7,9,10]$. Plasma levels of endothelin are elevated in ischemic heart disease and in heart failure $[26,27]$. Enhanced activity in the endothelin system has been associated with the progression of cardiovascular disease.
Endothelin is a strong vasoconstrictor and up-regulation of endothelin receptors on vascular smooth muscle cells causes inappropriate contraction that exacerbates atherosclerotic stenoses. Endothelin constricts human coronary arteries, especially those with atherosclerosis, and accounts for nearly all the resting tone at coronary artery stenosis [28]. Endothelin is also known to act as a mitogen on vascular smooth muscle cells, stimulate extracellular matrix synthesis and attract monocytes in the process of atherosclerosis.

We believe that it is important to gain insight into the regulation of the vascular endothelin receptor expression. Identifying the intracellular signal transduction pathways involved in the up-regulation of endothelin receptors may provide new pharmaceutical targets. Organ culture is an experimental model in which the endothelin receptor regulation can be studied in detail, ex vivo, to delineate the molecular mechanisms involved. Culture in the presence of different humoral factors or intracellular messenger inhibitors may reveal important pathways involved in the regulation of endothelin receptors. The method of organ culture combines the advantage of cell culturing techniques with the advantage of functional evaluation of intact blood vessels.

Increased endothelin $\mathrm{ET}_{\mathrm{B}}$ contraction after organ culture in the present study is presumably due to increased levels 


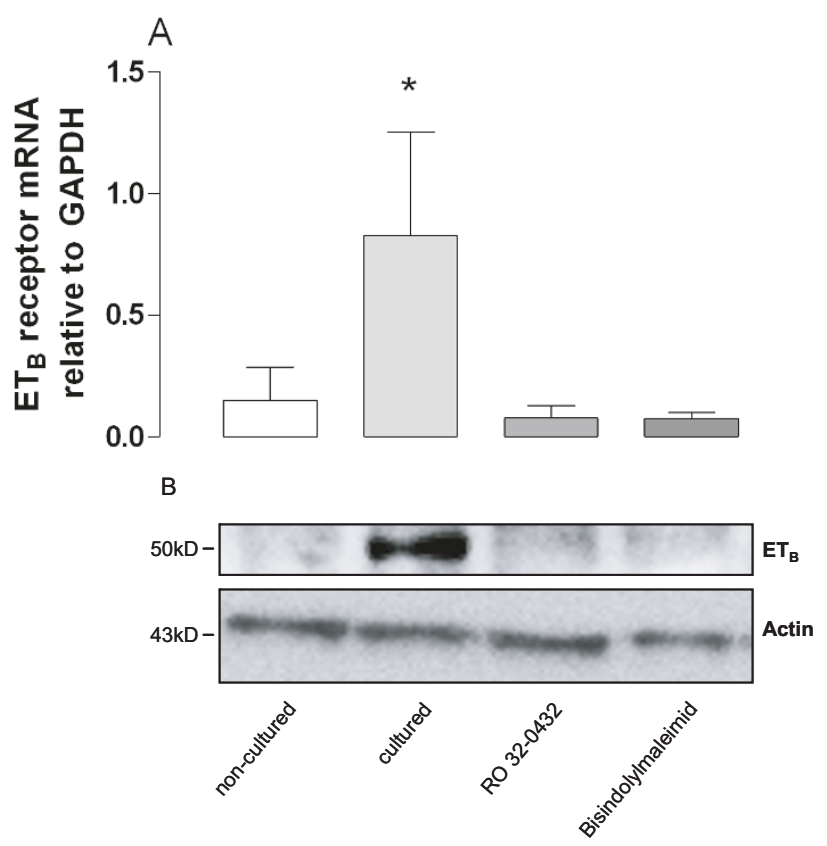

Figure 4

(A) The levels of endothelin $\mathrm{ET}_{B}$ receptor $\mathrm{mRNA}$ expression in human internal mammary arteries, examined using real time PCR. (B) Endothelin $E_{B}$ receptor protein expression in human internal mammary arteries, examined using Western blot. The arteries were either not cultured or cultured in the absence or presence of the protein kinase C inhibitors Ro-32-0432 or bisindolylmaleimide $\mathrm{I}$. The results are shown as mean values \pm S.E.M of six experiments. Endothelin $\mathrm{ET}_{\mathrm{B}} \mathrm{mRNA}$ levels in cultured and non-cultured arteries were compared using Student's t-test, where $\mathrm{P}<0.05\left(^{*}\right)$ was considered significant.

of contractile endothelin $\mathrm{ET}_{\mathrm{B}}$ receptors on the vascular smooth muscle cells. Previous results from our group show that the contractile response to sarafotoxin $6 \mathrm{c}$ in the human internal mammary artery is not significantly affected by removal of the endothelium [10]. This is in accordance with the current data since the arteries are obtained from patient with advanced coronary artery disease and probably generalized atherosclerosis and endothelium dysfunction.

\section{Mechanisms governing the regulation of endothelin $E T_{B}$ receptors}

We do not know the exact mechanism by which the endothelin $\mathrm{ET}_{\mathrm{B}}$ receptors are up-regulation in culture. Previous experiments suggest that the up-regulation requires physiological oxygen and glucose levels and that the choice of buffer solution (Krebs or DMEM) does not seem to play a role [29]. The dissection procedure is similar for the non-cultured and cultured arteries and does presumably not play a role for the organ culture effects. The only difference between the non-cultured and cultured vessel segments is incubation per se. During incubation, perfusion pressure is lost and we speculate that this loss in sheer stress may be one factor that triggers the receptor regulation. Indeed, preliminary perfusion experiments in vitro revile that the regulation of endothelin $\mathrm{ET}_{\mathrm{B}}$ receptors is dependent on the perfusion pressure applied (not published data). Up-regulation of $\mathrm{ET}_{\mathrm{B}}$ receptors is known to rely on increased transcription and subsequent translation of $\mathrm{ET}_{\mathrm{B}}$ receptor mRNA [30]. This is in accordance with the present results that demonstrate increased levels of $\mathrm{ET}_{\mathrm{B}}$ receptor mRNA and protein. In the human genome, the 5 '-flanking region of the genes encoding the endothelin receptors contain several regulatory elements, like GATA-motifs and E-boxes $[31,32]$. This indicates that the genes might be activated by for example stress related and inflammatory components.

\section{PKC signaling pathways}

This study was aimed to elucidate the role of the PKC and MAPK signaling pathways in the endothelin $\mathrm{ET}_{\mathrm{B}}$ receptor regulation. The PKC antagonists, Ro-32-0432 and bisindolylmaleimide I, each inhibited the increase in sarafotoxin $6 \mathrm{c}$ contraction and the elevated levels of endothelin $\mathrm{ET}_{\mathrm{B}}$ receptor protein and mRNA expression, during organ culture. PKC signaling pathways has previously been suggested to play a role in the development of cardiovascular disease. PKC increase oxygen production in the growing atherosclerotic lesion, leading to apoptosis and plaque instability [33]. The levels of PKC in the myocardium are elevated in various models of cardiac hypertrophy [3436]. Furthermore, PKC isozymes contribute to different stages of cardiac fibrosis [37]. Indeed, treatment with a PKC $\delta$ inhibitor has been shown to ameliorate the reperfusion injury during primary percutaneous coronary intervention for myocardial infarction [37].

\section{MAPK signaling pathways}

The MAPK pathways are thought to act downstream from PKC in the smooth muscle cell regulatory cascade [19]. MAPKs are a family of serine/threonine kinases which are associated with vascular smooth muscle cell contraction, migration, adhesion, collagen deposition, cell growth, differentiation and survival [38]. The three major subgroups of MAPK are p38, ERK1/2 and JNK [39]. In the present study we found that the p38 MAPK pathway inhibitor, SB203580 $(10 \mu \mathrm{M})$, the ERK1/2 pathway inhibitor, PD98059 $(10 \mu \mathrm{M})$ and the JNK pathway inhibitor, SP600125 $(10 \mu \mathrm{M})$, blocked the up-regulation of the endothelin $\mathrm{ET}_{\mathrm{B}}$ receptors in human internal mammary arteries during organ culture. This is in accordance with previous studies that have a role for MAPK pathways in cardiovascular disease. JNK is a stress-activated protein kinase while ERKs mediate cellular responses initiated by growth factors. The P38 MAPK pathway is activated by 

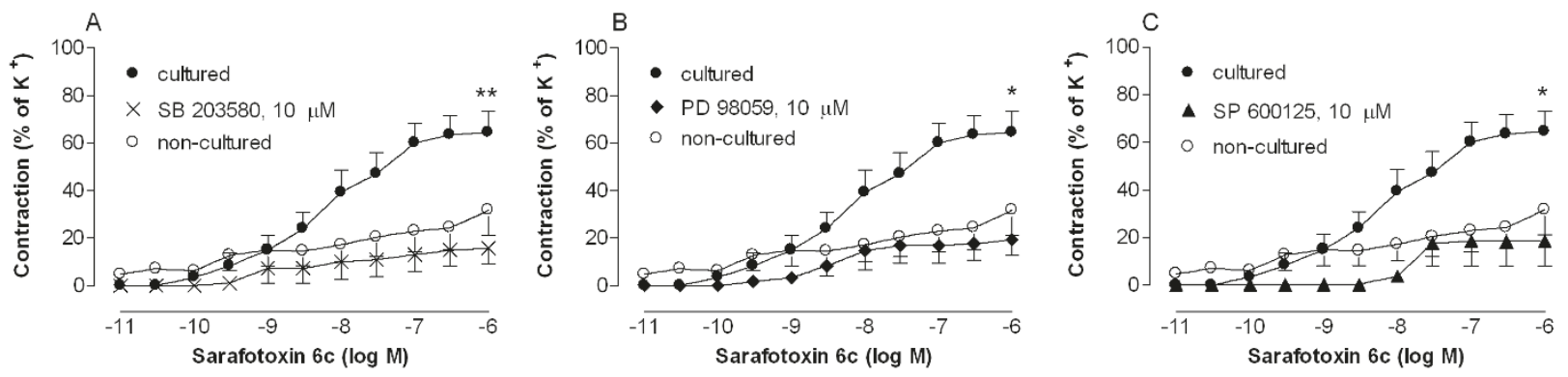

\begin{abstract}
Figure 5
Contractile responses elicited by cumulative application of the endothelin $\mathrm{ET}_{\mathrm{B}}$ receptor agonist sarafotoxin $6 \mathrm{c}$ in segments of human internal mammary arteries. The arterial segments were either not cultured or cultured in the absence or the presence of mitogen-activated kinase (MAPK) pathway inhibitors; (A) the P38 MAPK inhibitor SB203580, (B) the ERK I/2 inhibitor PD98059 or (C) the JNK inhibitor SP600I25. The results are shown as mean values \pm S.E.M of six experiments. Statistical analysis was performed using ANOVA with Dunnett's post-test for multiple comparisons. $P<0.05(*)$ and $P$ $<0.01\left({ }^{* *}\right)$ was considered significant. Comparisons were made between the results from arteries exposed to culture with and without SB203580, PD98059 or SP600I 25.
\end{abstract}

inflammatory cytokines such as TNF- $\alpha$, IL-1 and IL-8, which are known to be increased in atherosclerosis and ischemic heart disease. Since the vessels were obtained from severely diseased patients the current data may suggest that there is activation of all three major MAPKs in advanced cardiovascular disease.

\section{Clinical relevance}

Endothelin induces strong vasoconstriction in human blood vessels and endothelin receptors are up-regulated in cardiovascular disease such as hypertension, arteriosclerosis and myocardial infarction. Whether endothelin receptor antagonists will become part of the therapeutic armamentarium in hypertension and associated cardiovascular disease remains unclear. However, none of these agents is currently being developed for this indication. New endothelin antagonists devoid of side effects or alternative inhibitors of the endothelin converting enzymes may in the future become available to block the endothelin system [40]. Along with previous reports [16-18,41], the present study shows that the endothelin dependent vascular contraction and remodeling seem to be dependent on both PKC and MAPK. Inhibition of these intracellular signal tran sduction pathways may become a future approach for targeting the endothelin system in the prevention of the development of cardiovascular disease.

\section{Conclusion}

The present findings demonstrate up-regulated endothelin $\mathrm{ET}_{\mathrm{B}}$ receptors in human left internal mammary arteries after organ culture, which is similar to the changes that occur in cardiovascular disease. The intracellular signal transduction pathways PKC and p38 MAPK seems to be involved in the endothelin $\mathrm{ET}_{\mathrm{B}}$ receptor regulation. Inhibiting these intracellular signal transduction pathways may provide future therapeutic targets for hindering the development of vascular endothelin receptor changes in cardiovascular disease.

\section{Competing interests}

The authors declare that they have no competing interests.

\section{Authors' contributions}

DN helped in planning the experiments, performed the in vitro pharmacology and real time PCR experiments, analyzed the data and wrote the manuscript. LG performed the immunofluorescence experiments and reviewed the manuscript. AW helped in performing the in vitro pharmacology and real time PCR experiments and the analysis of the results. BG helped in performing the real time PCR experiments and analysis of the results. LE helped in planning the project and writing the manuscript. PP performed the surgical procedure and reviewed the manuscript. RI performed the surgical procedure and reviewed the manuscript. MM conceived the study, guided the experimental procedure and helped in writing ht manuscript.

\section{Acknowledgements}

This study was supported by the Åke Wiberg Foundation, the M. Bergvall Foundation, Anna Lisa and Sven-Eric Lundgrens foundation for medical research, the Anders Otto Swärds Foundation/Ulrika Eklunds Foundation, the Swedish Medical Association, the Royal Physiographic Society in Lund, the Swedish Medical Research Council, the Crafoord Foundation, the Swedish Heart-Lung Foundation, the Swedish Government Grant for Clinical Research and the Swedish Hypertension Society. 


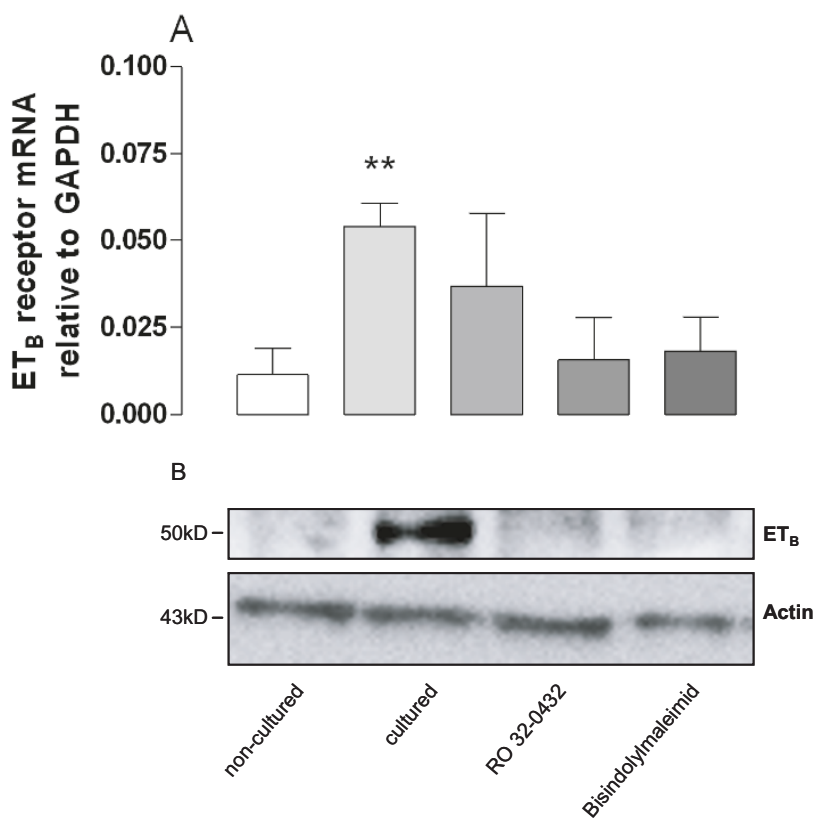

Figure 6

(A) The levels of endothelin $\mathrm{ET}_{\mathrm{B}}$ receptor $\mathrm{mRNA}$ expression in human internal mammary arteries, examined using real time PCR. (B) Endothelin $\mathrm{ET}_{B}$ receptor protein expression in human internal mammary arteries, examined using Western blot. The arteries were either not cultured or cultured in the absence or presence of mitogen-activated kinase (MAPK) pathway inhibitors; the P38 MAPK inhibitor SB203580, the ERK I/2 inhibitor PD98059 or the JNK inhibitor SP600I25. The results are shown as mean values \pm S.E.M of six experiments. Endothelin $\mathrm{ET}_{B}$ mRNA levels in cultured and non-cultured arteries were compared

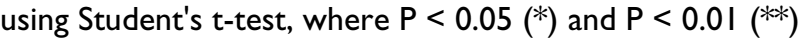
was considered significant.

\section{References}

I. Arai H, Hori S, Aramori I, Ohkubo H, Nakanishi S: Cloning and expression of a cDNA encoding an endothelin receptor. Nature 1990, 348:730-732.

2. Sakurai T, Yanagisawa M, Takuwa $Y$, Miyazaki H, Kimura S, Goto K, Masaki T: Cloning of a cDNA encoding a non-isopeptide-selective subtype of the endothelin receptor. Nature 1990, 348:732-735.

3. He GW, Liu MH, Yang Q, Furnary A, Yim AP: Role of endothelinI receptor antagonists in vasoconstriction mediated by endothelin and other vasoconstrictors in human internal mammary artery. Ann Thorac Surg 2007, 84: I522-I527.

4. Maguire JJ, Davenport AP: ETA receptor-mediated constrictor responses to endothelin peptides in human blood vessels in vitro. Br J Pharmacol 1995, I I 5:191-197.

5. Nilsson D, Wackenfors A, Gustafsson L, Ugander M, Paulsson P, Ingemansson R, Edvinsson L, Malmsjo M: Endothelin receptor-mediated vasodilatation: Effects of organ culture. Eur J Pharmacol 2008, 579:233-240.

6. Szok D, Hansen-Schwartz J, Edvinsson L: In depth pharmacological characterization of endothelin $B$ receptors in the rat middle cerebral artery. Neurosci Lett 200 I, 3 | 4:69-72.

7. Dagassan PH, Breu V, Clozel M, Kunzli A, Vogt P, Turina M, Kiowski $W$, Clozel JP: Up-regulation of endothelin-B receptors in atherosclerotic human coronary arteries. J Cardiovasc Pharmacol 1996, 27:147-153.
8. Cannan $C R$, Burnett JC Jr, Lerman A: Enhanced coronary vasoconstriction to endothelin-B-receptor activation in experimental congestive heart failure. Circulation 1996, 93:646-65I.

9. Wackenfors A, Emilson M, Ingemansson R, Hortobagyi T, Szok D, Tajti J, Vecsei L, Edvinsson L, Malmsjo M: Ischemic heart disease induces upregulation of endothelin receptor mRNA in human coronary arteries. Eur J Pharmacol 2004, 484: I03-109.

10. Nilsson D, Wackenfors A, Gustafsson L, Edvinsson L, Paulsson P, Ingemansson R, Malmsjo M: Increased ET(A) and ET(B) receptor contraction in the left internal mammary artery from patients with hypertension. J Hum Hypertens 2008, 22(3):226-229.

II. Adner M, Cantera L, Ehlert F, Nilsson L, Edvinsson L: Plasticity of contractile endothelin-B receptors in human arteries after organ culture. Br J Pharmacol 1996, I I 9: I I59- I I 66.

12. Wackenfors A, Emilson MIR, Edvinsson L, Malmsjö M: Ischemic heart disease down-regulates angiotensin type I receptor mRNA in human coronary arteries. Eur J Pharmacol 2004, 503(I - 3): I47-I53.

13. Hansen-Schwartz J: Receptor changes in cerebral arteries after subarachnoid haemorrhage. Acta Neurol Scand 2004, 1 09:33-44.

14. Lind H, Adner M, Erlinge D, Brunkwall J, Edvinsson L: Selective increase of the contractile response to endothelin-I in subcutaneous arteries from patients with essential hypertension. Blood Press 1999, 8:9-15.

15. Stenman E, Malmsjo M, Uddman E, Gido G, Wieloch T, Edvinsson L: Cerebral ischemia upregulates vascular endothelin ET(B) receptors in rat. Stroke 2002, 33:231I-2316.

16. Nilsson D, Wackenfors A, Gustafsson L, Ugander M, Ingemansson R, Edvinsson L, Malmsjo M: PKC and MAPK signalling pathways regulate vascular endothelin receptor expression. Eur J Pharmacol 2008, 580(I-2): I 90-200.

17. Henriksson M, Stenman E, Edvinsson L: Intracellular pathways involved in upregulation of vascular endothelin type $B$ receptors in cerebral arteries of the rat. Stroke 2003, 34:|479-|483.

18. Uddman E, Henriksson M, Eskesen K, Edvinsson L: Role of mitogenactivated protein kinases in endothelin ETB receptor up-regulation after organ culture of rat mesenteric artery. Eur J Pharmacol 2003, 482:39-47.

19. Schonwasser DC, Marais RM, Marshall CJ, Parker PJ: Activation of the mitogen-activated protein kinase/extracellular signalregulated kinase pathway by conventional, novel, and atypical protein kinase C isotypes. Mol Cell Biol 1998, I 8:790-798.

20. Hazzalin CA, Mahadevan LC: MAPK-regulated transcription: a continuously variable gene switch? Nat Rev Mol Cell Biol 2002 , 3:30-40.

21. Kaminska B: MAPK signalling pathways as molecular targets for anti-inflammatory therapy - from molecular mechanisms to therapeutic benefits. Biochim Biophys Acta 2005, I 754:253-262.

22. Högestätt ED, Andersson KE, Edvinsson L: Mechanical properties of rat cerebral arteries as studied by a sensitive device for recording of mechanical activity in isolated small blood vessels. Acta Physiol Scand 1983, I I 7:49-6I

23. Wackenfors A, Ingemansson R, Malmsjo M: Endothelin receptors in endothelium-denuded human coronary artery bypass grafts and coronary arteries. Ann Thorac Surg 2003, 75:874-88I.

24. Lodge NJ, Zhang R, Halaka NN, Moreland S: Functional role of endothelin ETA and ETB receptors in venous and arterial smooth muscle. Eur J Pharmacol 1995, 287:279-285.

25. Sokolovsky M: Endothelins and sarafotoxins: receptor heterogeneity. Int J Biochem 1994, 26:335-340.

26. Mundhenke M, Schwartzkopff B, Kostering M, Deska U, Klein RM, Strauer BE: Endogenous plasma endothelin concentrations and coronary circulation in patients with mild dilated cardiomyopathy. Heart 1999, 8 I:278-284.

27. Neunteufl T, Berger R, Pacher R: Endothelin receptor antagonists in cardiology clinical trials. Expert Opin Investig Drugs 2002, I I :43 I -443.

28. Kinlay S, Behrendt D, Wainstein M, Beltrame J, Fang JC, Creager MA Selwyn AP, Ganz P: Role of endothelin-I in the active constriction of human atherosclerotic coronary arteries. Circulation 2001, 104:1114-1118.

29. Adner M, Geary GG, Edvinsson L: Appearance of contractile endothelin-B receptors in rat mesenteric arterial segments following organ culture. Acta Physiol Scand 1998, 163:121-129. 
30. Moller S, Edvinsson L, Adner M: Transcriptional regulated plasticity of vascular contractile endothelin ET(B) receptors after organ culture. Eur J Pharmacol 1997, 329:69-77.

31. Arai H, Nakao K, Takaya K, Hosoda K, Ogawa Y, Nakanishi S, Imura $\mathrm{H}$ : The human endothelin-B receptor gene. Structural organization and chromosomal assignment. J Biol Chem 1993, 268:3463-3470.

32. Hosoda K, Nakao K, Tamura N, Arai H, Ogawa Y, Suga S, Nakanishi $\mathrm{S}$, Imura $\mathrm{H}$ : Organization, structure, chromosomal assignment, and expression of the gene encoding the human endothelin-A receptor. J Biol Chem 1992, 267:18797-18804.

33. Sorescu D, Weiss D, Lassegue B, Clempus RE, Szocs K, Sorescu GP, Valppu L, Quinn MT, Lambeth JD, Vega JD, et al.: Superoxide production and expression of nox family proteins in human atherosclerosis. Circulation 2002, 105:|429-|435.

34. Gu X, Bishop SP: Increased protein kinase $\mathbf{C}$ and isozyme redistribution in pressure-overload cardiac hypertrophy in the rat. Circ Res 1994, 75:926-931.

35. Inagaki K, Iwanaga Y, Sarai N, Onozawa Y, Takenaka H, Mochly-Rosen $D$, Kihara $Y$ : Tissue angiotensin II during progression or ventricular hypertrophy to heart failure in hypertensive rats; differential effects on PKC epsilon and PKC beta. J Mol Cell Cardiol 2002, 34: I377-I385.

36. Takeishi Y, Ping P, Bolli R, Kirkpatrick DL, Hoit BD, Walsh RA: Transgenic overexpression of constitutively active protein kinase $\mathbf{C}$ epsilon causes concentric cardiac hypertrophy. Circ Res 2000, 86:1218-1223.

37. Churchill E, Budas G, Vallentin A, Koyanagi T, Mochly-Rosen D: PKC Isozymes in Chronic Cardiac Disease: Possible Therapeutic Targets? Annu Rev Pharmacol Toxicol 2008, 48:569-599.

38. Yogi A, Callera GE, Montezano AC, Aranha AB, Tostes RC, Schiffrin EL, Touyz RM: Endothelin-I, but not Ang II, activates MAP kinases through c-Src independent Ras-Raf dependent pathways in vascular smooth muscle cells. Arterioscler Thromb Vasc Biol 2007, 27:1960-1967.

39. Tanoue T, Yamamoto T, Maeda R, Nishida E: A Novel MAPK phosphatase MKP-7 acts preferentially on JNK/SAPK and p38 alpha and beta MAPKs. J Biol Chem 200I, 276:26629-26639.

40. Schiffrin EL: Vascular endothelin in hypertension. Vascul Pharmacol 2005, 43:19-29.

41. Henriksson M, Xu CB, Edvinsson L: Importance of ERKI/2 in upregulation of endothelin type $B$ receptors in cerebral arteries. Br J Pharmacol 2004, I 42: I I55-I I6I.

\section{Pre-publication history}

The pre-publication history for this paper can be accessed here:

http://www.biomedcentral.com/1471-2261/8/21/prepub
Publish with Bio Med Central and every scientist can read your work free of charge

"BioMed Central will be the most significant development for disseminating the results of biomedical research in our lifetime. "

Sir Paul Nurse, Cancer Research UK

Your research papers will be:

- available free of charge to the entire biomedical community

- peer reviewed and published immediately upon acceptance

- cited in PubMed and archived on PubMed Central

- yours - you keep the copyright
BioMedcentral 